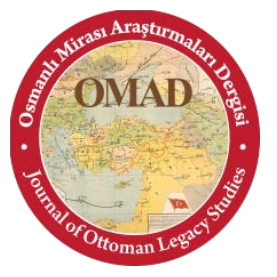

Osmanlı Mirası Araştırmaları Dergisi (OMAD) , Yıl 1, Sayı 1, Kasım 2014, ss. 71-73.

Journal of Ottoman Legacy Studies (JOLS), Volume 1, Issue 1, November 2014, pp. 71-73.

ISSN 2148-5704

\title{
Cemal Kurnaz-Halil Çeltik, Osmanlı Dönemi Kırım Edebiyatı, Kurgan Edebiyat, Ankara 2012.
}

\section{Ersin BAYRAM*}

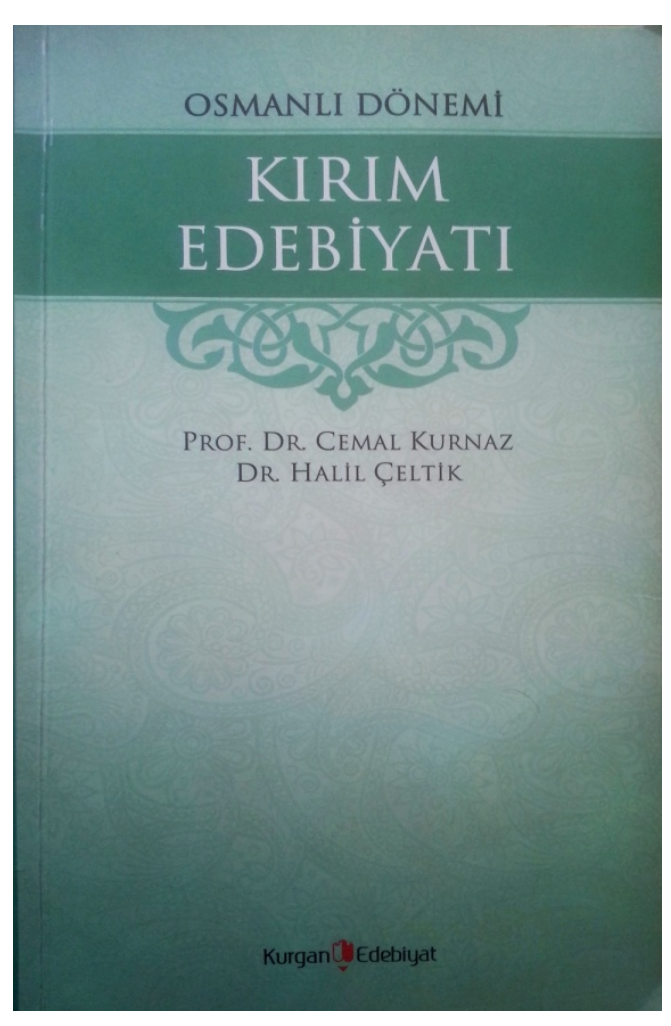

Bir bölgenin vatan edinilmesinden sonra ortaya konulmuş eserler, onları meydana getiren dil ve kültür ortamı var olduğu müddetçe millet hafızasında daima taze ve canlı kalır. Yaklaşık üç asır Osmanlı hâkimiyeti altında kalmış olan ve ardından Rus, Ukrayna ve 2014 yilında tekrar Rus kontrolüne giren Kırım için bu durum farklı bir anlam taşır. Kırım yarımadası Karadeniz'in kuzeyindeki stratejik konumuyla, siyasi, kültürel ve edebî yanıyla bizim için önemli bir merkez olmuştur. Uzun zaman hanliklar tarafindan yönetilen Kırım'da Osmanlı'nın tesis ettiği huzur ortamının bir sonucu olarak birçok şair ve yazar yetişmiştir. $\mathrm{Bu}$ yazıda tanıtılacak olan eser Osmanlı'nın bölgede bıraktığı edebî mirası konu almaktadır. Söz konusu çalışma, Cemal KURNAZ ve Halil ÇELTIKK tarafindan hazırlanıp ilk baskısı 2000 yılında (Kültür Bakanlığı Yay.) yapılan Osmanlı Dönemi Kırım Edebiyatı adlı eserdir.

Eser "Önsöz" (7-8)'den sonra "Osmanl1 Dönemi Kırım Edebiyatına Toplu Bir Bakış" (9-21) ve "Osmanlı Dönemi Kırım Şairleri" (23-228) olmak üzere iki ana bölümden oluşmakta, bunları "Kaynaklar ve Kısaltmalar" (229-234) ile "Dizin" (235-246) takip etmektedir.

Yazarlar "Önsöz"de eseri kaleme alırken izlemiş oldukları yöntem hakkında kısa bilgi verdikten sonra bu çalışmayı niçin yaptıklarını şöyle anlatmışlardır: "Büyük bir kısmı hanlar olmak üzere, Kırım'da çok saylda şair ve ilim adamı yetişti. Bursalı Mehmet Tahir Bey'in Osmanlılar Zamanında Yetişen Kırım Müellifleri isimli kitapçı̆̆ı sayılmazsa, Kırım Türk edebiyatının bugüne kadar araştırmacılardan yeterli ilgiyi gördüğ̈̈ söylenemez. Biz, bu eksikliği gidermek için, Osmanlı Dönemi Kırım edebiyatını ayrıntılı olarak ortaya koymaya çalıştık. (...) Biz, bu çalışmamızda, Osmanlı Dönemi'nde yetişen Kırımlı şairleri ilk defa bu kadar kapsaml şekilde ele alarak, bu konuya dikkat çekmiş bulunuyoruz. Burada ele alınan şahsiyetlerin büyük çoğunluğu tek tek monografik çalışmalara konu olabilecek niteliktedir. Bu çalışma araştırmacıların ilgisini bu konuya çekebilirse görevini yapmış olacaktır." (s. 7-8).

\footnotetext{
* Doktora öğrencisi, e-mail: ersinbayram12@hotmail.com
} 
Araştırmacıların "Önsöz"de belirttiklerine göre bu çalışmayla Kırımlı 56 şair tespit edilmiştir. Bu şairlerden bir kısmı eserin ilk bölümünde, diğer kısmı (31 şair) ise ikinci bölümde değerlendirilmiştir: "Çoğunluğu XVII. ve XVIII. yy.larda yaşamış 56 şair tespit ettik. (...) Burada yer alan bazı şairler hakkında kaynaklarda yok denecek kadar az bilgi ve şïr örneği bulunmaktadır. Çoğu ilk defa tespit edilen bu bilgiler, ilerideki araştırmalara yardımcı olacağ düşünülerek, kaynaklarıyla birlikte belirtilmiştir. Hakkında nispeten geniş bilgi ve şiir örneği bulunan şairler ise, ikinci bölümde ayrıntılı olarak ele alındiğından, burada kronolojiye uygun olarak, kaynak gösterilmeksizin kısaca zikredilmekle yetinilmiştir." (s. 7).

Eserin birinci bölümü beş alt başlıktan oluşmaktadır. "Kırım'ın Tarihine Kısa Bir Bakış" başlığıyla Kırım'ın MÖ 1250'lere kadar götürülebilen tarihinden başlayan ve 1476'da Osmanlı'ya bağlanıp 1783'te Rusların ilhakına kadar geçen sürece kısaca değinilmiştir. Burada iktidar ve sanat arasındaki bağın önemine "Kırım, güçlü hanlar ve yöneticiler zamanında, sanat ve edebiyat için uygun bir istikrar ortamı bulmuş, yeteneksiz idareciler zamanında meydana gelen kargaşa içinde sanatçılar ülkelerini terk etmek zorunda kalmışlardır." denilerek Kırım hanlarının şairlere destek olmasının üzerinde durulmuştur. "Kırım Türk Edebiyatının Başlangıcı" başlığı altında Kırım'daki Türk edebiyatının halk edebiyatı ve klasik edebiyat olmak üzere iki kola ayrıldığı, Osmanlı hâkimiyetine kadar Çağatay lehçesinin, ondan sonra ise Osmanlı Türkçesinin hâkim olduğu belirtilmekte ve eserin amacının Osmanlı sahasındaki edebiyata paralel olarak gelişen edebiyat ile onun verilerini incelemek olduğu kaydedilmektedir. "Han Soylu Şairler" başlığı altında ise Kırım hanlarından ilim ve edebiyata meraklı oldukları dile getirilmiş ve şiirle uğraşan hanlar kronolojik sıraya göre kısaca tanıtılmıştır. "Osmanlı Dönemi Kırım Edebiyatına Toplu Bakış" kısmında ise -hanların şiirle uğraşmasının da tesiriylebölgede pek çok şair yetiştiği ifade edilip bu dönemde yetişen şairlerin bir kısmı hakkında kısa kısa bilgiler verilerek bazılarının dikkate değer beyitleri yazılmıştır. "Rus İşgalinden Sonra Kırım Edebiyatı" ismini taşıyan son başlıkta ise Gaspıralı'nın faaliyetlerine kısaca değinilmiş, I. Dünya Savaşı'nın ardından Kırım ve İstanbul arasındaki bağın koptuğu belirtilmiştir.

İkinci bölüm "Osmanlı Dönemi Kırım Şairleri" başlığını taşımaktadır. Bu bölümde şairlerin biyografik bilgileri kronolojik sıraya göre yazılmış, kaynaklar vasıtasıyla ulaşılan veriler sunulmuş, şairlerin eserlerinin isimleri verilerek şairler üzerine kimlerin çalışma yaptığına değinilmiştir. Ardından tezkireler, edebiyat tarihleri, Sicill-i Osmanî, Kamusu'l-A'lâm, Meşhur Adamlar, Mecelle, birçok şair için tek kaynak olma özeliği taşıyan Seb'u's-Seyyâr, Fezleke, Kırım Müellifleri, Gülbün-i Hânân, şahıslar veya dönemler hakkında yazılmış makaleler gibi eski ve yeni bütün kaynaklar verilmiştir. Kaynakçanın ardından örnek metinler seçilmiş olup bu metinlerin de nereden alındığı gösterilerek, metinlerin günümüz Türkçesine çevirileri yer almıştır.

Eserin ikinci bölümünde tanıtılan ve şiirlerinden örnekler verilen şairler şunlardır: Yûsuf ile Zelihâ mesnevisiyle Anadolu'daki dinî edebiyatın müjdecilerinden kabul edilen Ali, Mahmud, Emîr Sultan'a manevi bir yakınlık duyup menakıbını yazan Müdâmî, Bakayî, Hüseyin Efendi, Kırım hanlarının en önemlilerinde olan şair, hattat, müzisyen ve bestekâr Gazâyî (Gazi Giray), Afîfî, Rezmî (Bahadır Giray Han), Kelîmî, Vecîhî, Şefí'î, bazı şiirleri Gevheri'ye isnat edilen Kâmil (Kırım Hanı IV. Mehmed Giray), İzzî, Âlî, Lutfî, iyi derecede Arapça ve Farsça bilen, hafiz, Mesnevî́yi ezberlemiş bir Mevlevî, Hafız Post ve Itri’yi himaye etmiş önemli bir hâmi, büyük bir cengâver olan Selim Giray, "Elâ gözlerine kurbân olduğum" isimli şiiri Sadettin KAYNAK tarafindan hicaz makamında bestelenmiş Âşık Ömer, Kırımî, Şâhî (Şahin Giray), Gevherî, Nevâî (II. Mengli Giray Han), Rahmî, tevhit konusunda yazılmış Burhanü'l-Ârifîn ve Necâtü'l-Gâfilîn isimli önemli bir eseri de olan Selim Dîvâne, Besim, Râmiz, Gülbün-i Hânân müellifi Halîmî (Halîm Giray), Rif'at, Sîretî (Şahbaz Giray), Fâzıl, Şerîf ve Nüzhet.

"Kaynaklar ve Kısaltmalar" kısmında eser kaleme alınırken faydalanılan kaynaklar alfabetik sıraya göre yazılmış, ardından da "Dizin" verilmiştir. 
Osmanlı Dönemi Kırım Edebiyatı, Kırım edebiyatı ve bölgede yetișen șairler hakkında yazılan en kapsamlı eser olması, şairlerin şiirlerinden seçmeler vererek bir Kırım şairleri antolojisi olma özelliği göstermesi ve daha önce tespit edilmemiş yeni şairler hakkında bilgiler vermesi bakımından önemlidir.

Son söz olarak Yahya Kemal, Üsküp için "Üsküp ki Şar Dağı'nda devamıydı Bursa'nın" der. Bu çalışmaya bakarak biz de "Kırım ki Karadeniz'den sonrasıydı Sinop'un" diyebiliriz. 